\title{
V. Second reply to Mr. De Luc's observations on a paper entitled "reflections on the inadequacy of the principal hypotheses to explain the phænomena of electricity."
}

\section{Dononan Esq.}

To cite this article: M. Dononan Esq. (1815) V. Second reply to Mr. De Luc's observations on a paper entitled "reflections on the inadequacy of the principal hypotheses to explain the phænomena of electricity." , Philosophical Magazine Series 1, 46:207, 13-14, DOI: 10.1080/14786441508638484

To link to this article: http://dx.doi.org/10.1080/14786441508638484

$$
\text { 央 Published online: } 27 \text { Jul } 2009 .
$$

Submit your article to this journal ए]

$$
\text { Џll Article views: } 2
$$

Q View related articles $\sqsubset$ 
V. Second Reply to Mr. Dr Lur's Olservations on a Paper entitled "Reflections on the Inadequacy of the principal Hypotheses to explain the Phanomenc of Electricity." By M. Dovonax, Esq.

\section{To Mr. Tilloc?.}

$S_{1 R},-I_{N}$ my former reply to Mr. De Lue, Declared thas 1 had no intention of supporting any electrical hypothesis; on the contrary, I wished to show that we are deceived when we suppose ourselves posessed of any knowledge on the snivect beyond facts. I did not intend to athrm that Mr. De Luc's experiment, in which unelectrified pith-balls brought into a positive atmosphere appeared nematively electrified, could be justly explained by the hypothesis of Franklin; inasmuch as I conceived this hypothesis to be itself unfounded; but merely that it had as good clain; a; any other. My intention was to show that even Volta's doctrine iv intencl, and that Mr. De Luc's experinent brouglt forward in supprost of it, is better explicalle on the views of Frankin, even though the Funlinian system is in general el* roneous, shan on the views of Volan: and therelore, that the experiment in que cion did not esthty the opinions of the lattert philocopher. My reasons for supposing this 1 have stated to be as follows. Whin the unelectriced bails were brought into a room where a yowerful clectric in whine was dispering positi" electricity, tiray diverged negatively; and this I conceived night as well be explained by the agenoy of electric injutuences, as an experiment of mine in which siriluty electrifed bocies attractes each other, and when Mr. De Lut aceounts for by the same inAluences. I thertore considered that I had an equal clain to auppose the positive aturosphere to have repelled the natur"? electriciry of the bals into their intericr substance, and virtualls to have laft the exterior minus. Witl: this I considered the si:guel to comespond. When the balls were removed into the m"electritied room, they lost their divergenee, berawse the camse which induced the minus state in the balls being ramoyed, tive quantity natural to the balls might receive its fomer dictribr. tion, and therefore appear in the natwal state. Ent in using the expression nutual state, I have not made myselt miderstors? to $\mathrm{Mr}$. De Luc. I did not mean the natural st dite as laid down by Franklin. I conceived, even adinitting the standard natual state assumed by Volta, that the balls should resume their nox:electrifed appearance. For admit this standard to be variaive, is it probable that there was any variation in so short a periol as that ccerpier by the experiment, when it appears that the ball: had trot ti:uc to absorb caly electricity from the positive at- 
mosphere; and not to speak of probability, what proof can be adduced that there was a variation?

As to the theory of electric influences, I am at a loss to understand upon what basis it is founded. It appears to me to be an adaptation of an hypothetical principle supported by facts which admit of a different explanation equally. In short, throughout all the hypotheses of electricity which have come within my limited knowledge, the proofs are derived from the thing to be proved, and have this property, that when the reasonings are pursued in all their evolutions, the inquirer invariably arrives at the place from whence he set out.

The other principal topic on which Mr. De Lue is not satisfied, is my assertion of the permeability of glass; and he states that his explanation of the Leyden phial is founded on a supposition of the contrary. Mr. De Lue also declares himself disinclined at this advanced and infirm period of his life to mudertake any new experiments, but suggests one to me for trial. The least possible return that can be made to a philosopher who has $\mathrm{cm}$ ployed a long life in labours so creditable to himself and serviceable to the cultivators of science, would be to exccute his suggestions, but that the circumstances have rendered it mnceessary. Mr. De Juc will find by relerring to my first paper on this subject, that I was avare of the objection, and had provided against it; he will then probably agree with me that glass is permeable to the electric fluid.
I have the honour to be, sir,
Your humble servant,
Dublin, June $21,18 ' 5$.
M. Donovan.

11. Destruction of the Viewers and Overmen at Sheriff Hill
Colliery. By A Correspondent.

To Mr. Tilloch.

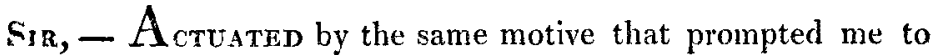
write you an account of the shocking accidents which befel the workmen in Heaton and Newbottle colliery a short time since, I now transmit the particulars of an explosion at Sheriff Hill; not so destruetive of human beings as either of those catastrophes, though highly distressing in its consequences; for on the present occasion all the managing and experienced miners employed in the concern have lost their lives. The mine at Sheriff Hill is situated on the elevated ground forming the southern banks of the vale of Tyne opposite Newcastle, from whence its distance is between two and three miles. Here the low main 